\title{
Past and Future Impact of Deep Drilling in the Oceanic Crust and Mantle
}

BY HENRY J.B. DICK, JAMES H. NATLAND, AND BENOIT ILDEFONSE

\section{AN EVOLVING ORDER OUT OF NEW COMPLEXITY}

Knowledge of the composition of oceanic crust is critical for calculating the fluxes of mass, heat, and volatiles from Earth's interior to its crust, oceans, and atmosphere. In the great debate over continental drift, Alfred Wegener claimed the oceanic crust, when explored, would prove to be nothing like the continental crust. Scientists have been fighting over its nature ever since, although it is clear that Wegener had it right. In his seminal paper, The History of Ocean Basins (Hess, 1962), Harry Hess argued: "The oceanic crust is serpen-

Henry J.B. Dick (hdick@whoi.edu) is Senior Scientist, Geology and Geophysics, Woods Hole Oceanographic Institution, Woods Hole, MA, USA. James H. Natland is Professor of Marine Geology and Geophysics, Rosenstiel School of Marine and Atmospheric Science, University of Miami, Miami, FL, USA. Benoit Ildefonse is CNRS researcher, Geosciences Montpellier, Université Montpellier 2, Montpellier, France. tinized peridotite, hydrated by release of water from the mantle over the rising limb of a current. In other words it is hydrated mantle material." In his view, the seismic structure and thickness of the oceanic crust was the product of metamorphic isograds, with the Mohorovicic Discontinuity (Moho; the boundary between the crust and upper mantle) an alteration front at the $500^{\circ} \mathrm{C}$ isotherm. By 1971, however, a consensus arose supporting the Penrose Ophiolite Model (Conference Participants, 1972). This consensus was spurred by dredging basalt of amazingly uniform composition along ocean ridges (Engel et al., 1965) and identifying fossil sections of on-land oceanic crust (known as ophiolites). The latter, often exhibiting a layered stratigraphy of pillow lava, sheeted dikes, gabbro, and mantle peridotite (Figure 1a), matched the seismic character of the oceanic crust and rocks dredged from fracture zones (Bonatti et al., 1971; Engel and Fisher, 1969). Seafloor mapping at slow and ultraslow spreading ridges, and deep drilling, however, are dissolving this consensus in favor of an oceanic crust whose composition, structure, and thickness vary with spreading rate, hot spot proximity, ridge geometry, and mantle temperature and composition.

Deep ocean drilling started as a wild idea floated by Walter Munk of Scripps Institution of Oceanography to Princeton geologist Harry Hess after a National Science Foundation Earth Science panel, where after reviewing 57 solidly incremental proposals, they thought: "Why not propose something really big instead-why not drill to the mantle?" The two scientists took this idea to the American Miscellaneous Society (AMSOC) for action, and in April 1957, this self-declared eclectic group of leading scientists gathered one sunny morning in La Jolla, California for breakfast at Dr. Munk's house-and ocean drilling was born. Their adventures-test drilling the AMSOC hole in Puerto Rico and drilling on a modified Navy freight barge, the CUSS 1-are told in the book: A Hole in the Bottom of the Sea (Bascom, 1961). Their Project Mohole, however, 


\section{Ocean Ridge Crustal Accretion Models}

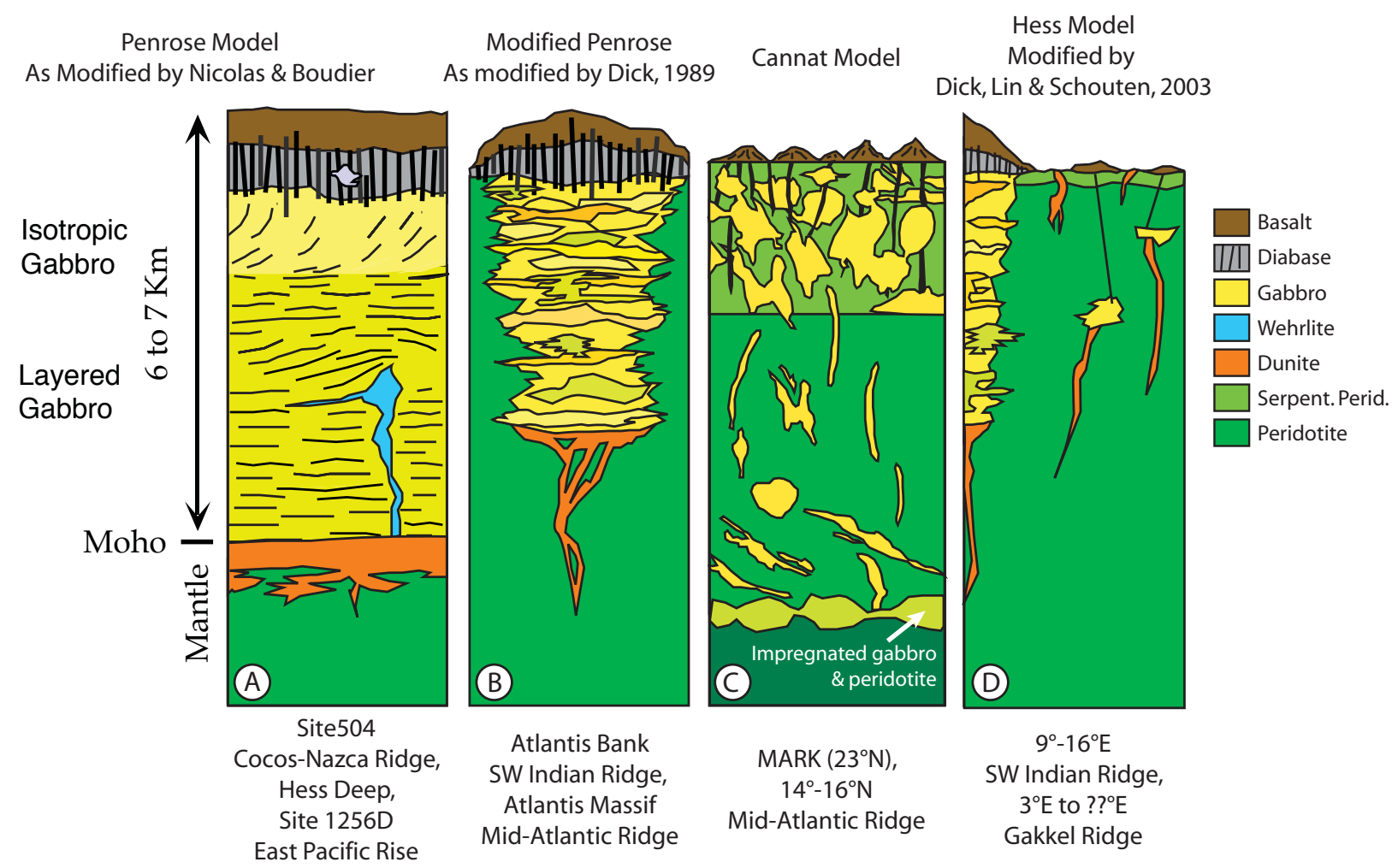

Figure 1. Models for crustal accretion at ocean ridges. A. Classic interpretation of the Penrose Model for a fast spreading ridge based on the Oman Ophiolite. B. Penrose model as modified for slowspreading ridges based on the abundance of peridotite and frequent absence of gabbro at transforms following focused melt-flow models. C. Model for the anomalous $14^{\circ}-16^{\circ} \mathrm{N}$ area of the Mid-Atlantic Ridge. D. Model for magmatic and amagmatic accretionary segments at ultraslow spreading ridges. It is unknown how far Hess type crust extends along Gakkel Ridge as the ridge is unsurveyed east of $85^{\circ} \mathrm{E}$.

foundered in runaway budgets, Congressional scandal, and sweetheart contracts during the Johnson administration. For many years, scientists avoided the word "Moho" anywhere near Washington. Out of these ashes, though, rose a more modest Deep Sea Drilling Project (DSDP) to drill long sediment cores and investigate seafloor spreading. Deep drilling, though, remained in the scientists' hearts, creeping back into the drilling program to greatly modify our understanding of the oceanic crust.

\section{OCEAN-CRUST MODELS}

Since the early ocean-crust models, much has changed. While the Penrose model is widely accepted for Pacific crust created at fast-spreading mid-ocean ridges, that is not the case for other oceans. In various ocean-crust models, the role of gabbro is critical, varying from the fundamental building block in the Penrose model, to minor or negligible importance in newer ones (Figure 1). Gabbro crystallizes slowly deep in the Earth and varies widely in composition; it forms as different minerals successively crystallize from magma and aggregate on the roof, walls, and sides of an intrusion or magma chamber. The first such aggregation to form from a mantle melt is the rock dunite, consisting of nearly pure olivine. Dunite marks the location where melts first emerge into the crust, and it fills the melt transport conduits in the mantle. Dunite, and gabbros with arcane names (e.g., troctolite, olivinegabbro, gabbronorite, oxide-gabbro), form complex stratigraphies reflecting 
the mechanical and chemical processes by which magmas are emplaced and solidify in the crust. Obtaining long sections of gabbro is, therefore, a major objective of drilling.

Dredging at Indian and Atlantic Ocean transform faults where faulting cuts deep into the oceanic crust, however, shows that locally it consists of depleted mantle peridotite overlain by lavas (a depleted peridotite has had basalt removed by partial melting). At the same time, deep drilling and mapping at the Atlantis II Fracture Zone on the Southwest Indian Ridge documents an enormous $400-\mathrm{km}^{2}$ gabbro massif next to the transform (Dick et al., 2000; Matsumoto et al., 2002). These data show that oceanic crust generated at slow- and ultraslow mid-ocean ridge spreading centers can consist of a gabbro massif centered beneath a magmatic ridge segment overlain by pillow lavas and dikes that extend down-axis over and into mantle peridotite at segment ends (Figure 1b) (Dick, 1989a). This structure suggests focused melt flow in the mantle towards ridge segment-midpoints (Whitehead et al., 1984).

Cannat $(1996,1997)$ noted massive exposures of serpentinized peridotite (peridotite that has been oxidized and hydrolyzed into serpentine) intruded by gabbro plugs on rift valley walls near $15^{\circ} \mathrm{N}$ on the Mid-Atlantic Ridge (MAR). She proposed that the lower crust at slow-spreading ridges consists of variously intruded serpentinized peridotite overlain by a thin carapace of pillow basalt and dikes (Figure 1c). Impressed by a scarcity of dikes exposed on fault scarps on transform fault and rift valley walls, Karson (1998) further suggested the absence of a uniform sheeted-dike layer at slow-spreading ridges, and that the structural relationships "reflect a sputtering magma supply and/or heterogeneous magmatic accretion across axial valleys over periods of tens to hundreds of thousands of years." Moreover, "Structurally complex oceanic crust that lacks a simple layered structure is likely to be a typical product of many slow spreading ridges."

By dredging and mapping at ultraslow spreading ridges, scientists have found long (80 km plus) amagmatic spreading segments replacing transform faults and magmatic spreading segments (Dick et al., 2003; Michael et al., 2003). Faulting at amagmatic segments exposes crust comprised of massive serpentinized peridotite, virtually no gabbro, and a thin or absent volcanic carapace (Figure 1d). These amagmatic segments are a newly recognized plate-tectonic structure, which can assume any angle to the plate spreading direction, and link to magmatic segments to form the plate boundary. Thus, coming full circle, true "Hess-type" oceanic crust (serpentinized peridotite) has been found.

Rather than refuting any of these models, deep drilling seems to show that each may describe crust formed at different locations on the global mid-ocean ridge system.

\section{DEEP-DRILLING RESULTS}

About 50 holes were drilled into "intact" sections of oceanic crust, beginning with the DSDP in 1974 until the start of the Integrated Ocean Drilling Program (IODP) in 2004, where it was believed that layered crust, such as described in the Penrose model (Figure 1a), existed in the Atlantic and Pacific Oceans. Only at Hole 504B south of the Costa Rica Rift, and possibly at Hole 418A in 108-million-year-old MAR crust, however, was seismic layer $2 \mathrm{~B}$ penetrated, with only Hole 504B possibly reaching the very top of seismic layer 3 (Alt et al., 1993; Detrick et al., 1994; Dick et al., 1992). Drilling in young Pacific crust was particularly difficult, with 10 holes in crust less than 30 million years old reaching a maximum penetration of only $178 \mathrm{~m}-$ a result attributed to the difficulty of drilling abundant glassy (extrusive volcanic) sheet flows. Success was better at slower-spreading ridges, with seven holes penetrating greater than $200 \mathrm{~m}$, and three reaching greater than $500 \mathrm{~m}$ (Figure 2). These drilling successes showed that seismic layer $2 \mathrm{~A}$ was composed of basalt lavas and rubble, and that at an intermediate spreading ridge, seismic layer $2 \mathrm{~B}$ was sheeted dikes as in the Penrose model. Surprisingly, short sections of often brecciated serpentinized peridotite and gabbro, exhibiting high-temperature alteration and crystal-plastic deformation, were found in six Atlantic holes drilled into supposedly "intact" oceanic crust. These drilling results demonstrated unexpected tectonic complexity that does not fit the simple Penrose model.

The early failure to drill deeply into oceanic crust was a huge disappointment. Other than sporadic drilling at Hole 504B, no serious attempt to drill oceanic crust was made for many years after DSDP Leg 53 (March-April 1977). Drilling difficulties were attributed to the presence of highly fractured basalt and diabase and possibly thermal problems deep in Hole 504B, though these were likely due as much to not properly 


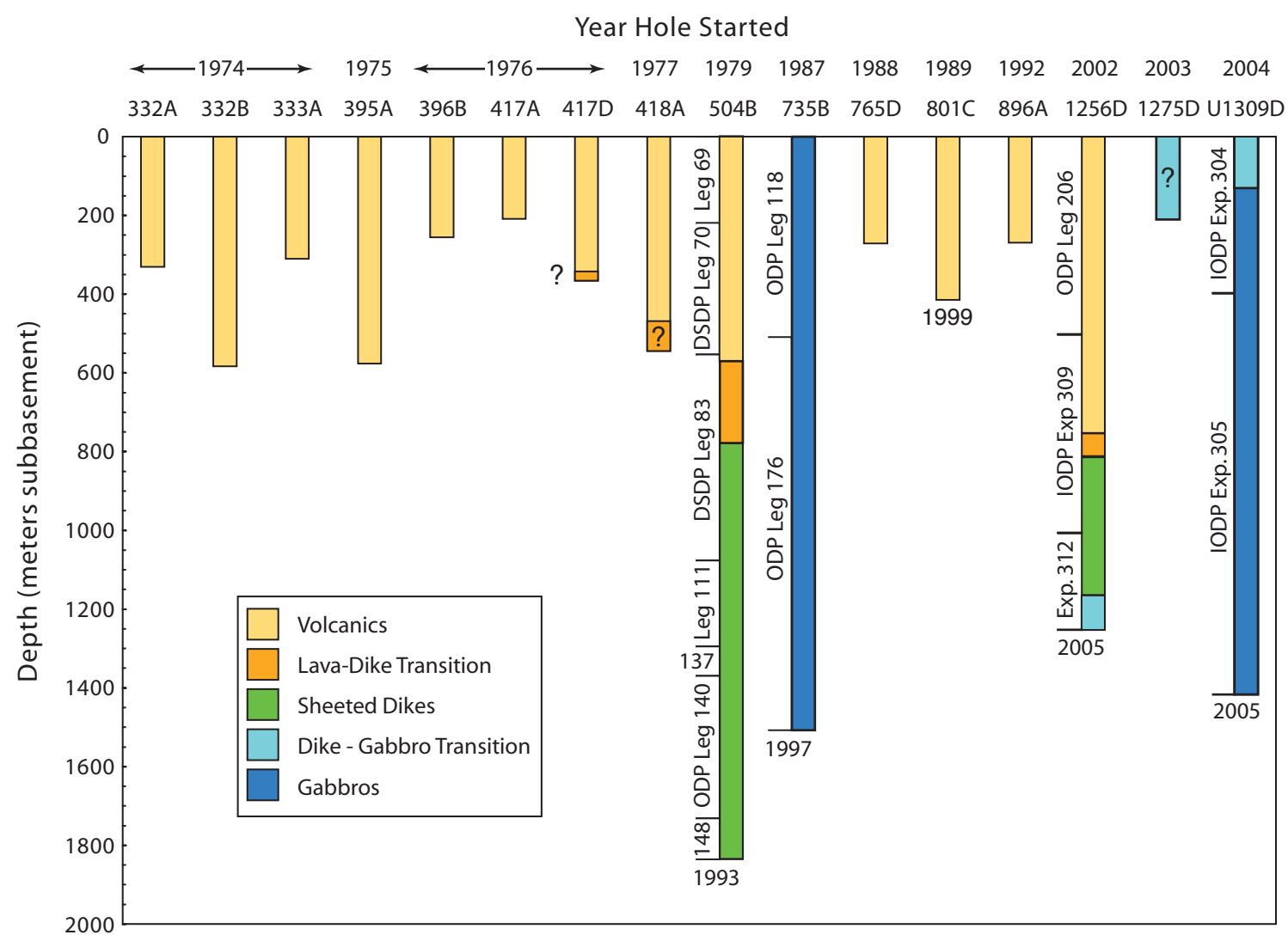

Figure 2. Ocean-basement holes drilled over 30 years extending deeper than $200 \mathrm{~m}$. Both U1309D (Mid-Atlantic Ridge) and 735B (Southwest Indian Ridge) are cut by dikes at the top of the section, and were likely unroofed at the dike-gabbro transition. The dike-gabbro transition at Hole U1309D is inferred in this paper, as is the lava-dike transition for Holes 417D and 418A in old Atlantic Ocean crust. Diabase intruding Hole 1275D gabbros may represent a sill complex rather than dikes (Kelemen et al., 2006). Drill hole locations are as follows: DSDP Leg 37 drilled holes 332A, 332B, and $333 \mathrm{~A}$ into the Mid-Atlantic Ridge at $36^{\circ} \mathrm{N}$. DSDP Leg 45 drilled Hole 395A 664 mbsf into oceanic crust in the Atlantic Ocean at $22^{\circ} 45^{\prime} \mathrm{N}, 46^{\circ} 5^{\prime} \mathrm{W}$. DSDP Leg 51A drilled Hole 417A, Leg 51B drilled Hole 417D, and Legs 52 and 53 drilled Hole 418A into oceanic crust in the western Atlantic Ocean south of Bermuda. Hole 504B, drilled on seven DSDP and ODP legs to a final depth of over $2 \mathrm{~km}$, is south of the Costa Rica Rift in the Pacific Ocean. ODP Hole 735B drilled into a shallow platform in the rift mountains of the ultra-slow Southwest Indian Ridge spreading center. ODP Hole 765D was drilled into old oceanic crust (Argo Abyssal Plain) off of northwest Australia. ODP Hole 801C was drilled into old western Pacific oceanic crust, seaward of the Mariana trench. ODP Hole 896A was in the Costa Rica Rift, eastern Pacific Ocean. IODP Hole 1256D was drilled into super-fast spreading rate crust in the equatorial Pacific Ocean. IODP Hole U1309D was drilled into the Atlantis Massif along the western flank of the Mid-Atlantic Ridge near $30^{\circ} \mathrm{N}$.

designing holes for deep penetration. Thus, a new strategy was adopted during the Ocean Drilling Program (ODP), using "tectonic windows" to drill lower crust and mantle (Dick, 1989b; Dick and Mével, 1996). This drilling strategy targeted peridotite and gabbro exposed at topographic highs at ridge-transform intersections: the Atlantis Bank at the Atlantis II Fracture Zone on the South- west Indian Ridge; the Mid-Atlantic Ridge-Kane Fracture Zone intersection (MARK) at $23^{\circ} \mathrm{N}$; and the Atlantis Massif at the Atlantis Fracture Zone at $30^{\circ} \mathrm{N}$ on the MAR. ODP also drilled on tectonic blocks that exposed peridotite and gabbro in the rift mountains north and south of the $15^{\circ} 20^{\prime}$ Fracture Zone on the MAR, and at Hess Deep in the Pacific, where the amagmatic tip of the
Cocos-Nazca rift propagates into young (1.5-2 million-year-old) East Pacific Rise crust. The "tectonic window" drilling strategy produced spectacular successes at ODP Hole 735B at Atlantis Bank and at IODP Hole U1309D at Atlantis Massif, which were drilled to $1508 \mathrm{~m}$ and $1415.5 \mathrm{~m}$, respectively. Although drilling at Hess Deep in the equatorial Pacific and at the MAR near the $15^{\circ} 20^{\prime}$ Fracture 
Zone produced relatively short sections of lower crust and mantle, these provided our first look at the internal stratigraphy of the deep crust and shallow mantle, supporting the Penrose model for Pacific crust, while showing that the Cannat model fitted the $15^{\circ} 20^{\prime}$ region of the Mid-Atlantic Ridge.

In 1987, ODP Leg 118, staffed by eager mantle petrologists, drilled 17 failed holes at the Atlantis II Fracture Zone (Southwest Indian Ridge), attempting to penetrate mantle exposed on the transform wall at a slow-spreading center. These drilling failures proved that fracture zones have a lot of fractured rock and are floored by debris flows and turbidites. With seventeen days left to drill, Hole 735B was drilled $504.5 \mathrm{~m}$ into a smooth bare-rock surface in 11 million-year-old crust on Atlantis Bank (a $25 \mathrm{~km}^{2}$ wave-cut platform at 700-m water depth at a high on the transform wall). ODP coring sampled massive gabbro with 87 percent recovery (Robinson et al., 1989). Two dikes $(1.5 \mathrm{~m})$ were drilled in the upper $150 \mathrm{~m}$ of the hole. Hole 735B was reoccupied in 1997 by ODP Leg 176 and deepened to 1508 meters below seafloor (mbsf), when the drill pipe broke off in a storm and free-fell to the bottom of the hole, permanently blocking it (Dick et al., 1999). The gabbros have the physical properties of seismic layer 3, consistent with the Penrose model, and sufficient magnetization to account for the overlying sea-surface anomaly. A 154-m-deep offset hole, 1105A, drilled $1 \mathrm{~km}$ to the northeast on ODP Leg 179, recovered essentially the same stratigraphy as the top of Hole 735B, demonstrating its lateral continuity.
Drilling at Hole 735B changed how lower crust was viewed at slow-spreading mid-ocean ridges (Dick, 1991a; Sinton and Detrick, 1992). The section was complex, with 952 igneous intervals described by mineralogy, grain size, and texture. It becomes more primitive and olivine-rich downward, consisting of dominantly olivine gabbro, intrusions. These intrusions are overprinted by interstitial late iron-rich melt redistributed towards the top of the section by deformation and compaction prior to complete solidification (Dick et al., 2000). Thus, the section reflects numerous small intrusions and melts working their way upwards through partially solidified lower crust in a tectonically active environment and not upward differentiation of a huge magma chamber-the paradigm for the lower crust when the Penrose model was formulated (e.g., Cann, 1974).

In November 2004, in an attempt to drill fresh mantle peridotite, IODP Expeditions 304 and 305 (again staffed by eager mantle petrologists) drilled Hole U1309D $1414.5 \mathrm{~m}$ into the Atlantis Massif (Blackman et al., 2006). The hole is located $\sim 5 \mathrm{~km}$ north of massive serpentinized peridotite cropping out at the top of the transform wall and $1.4 \mathrm{~km}$ east of a seismic line giving mantle velocities only several hundred meters below seafloor (Blackman et al., 1998; Collins and Detrick, 1998; Collins et al., 2001)_well within drilling range. Drilling was successful, with an open hole drilled to $1415 \mathrm{~m}$ with 75 percent core recovery. The rocks recovered were a complete surprise, however, consisting of 0.3 percent peridotite in the top $100 \mathrm{~m}$ of the hole, 2.9 percent dikes (mostly in the upper $200 \mathrm{~m}$ ), and 97.8 percent gabbro with minor dunite. These cores were NOT the result expected from interpretation of the seismic records. While also having a highly complex igneous stratigraphy, unlike Hole 735B, there is no downward trend to more primitive gabbro, the hole bulk composition appears different, alteration was mostly at lower temperature, and high-temperature crystal-plastic deformation is rare-showing that full knowledge of gabbroic crust in the oceans requires drilling more than a single long section.

The MAR near the $15^{\circ} 20^{\prime}$ Fracture Zone has huge peridotite exposures. Dredging and submersible dives suggest a crust consisting of small gabbro intrusions in screens of serpentinized peridotite cut by dikes, and overlain by a thin basaltic carapace (Cannat, 1993, 1996; Cannat et al., 1995). Basalt trace element and isotopic compositions (Dosso et al., 1991), and the extremely depleted peridotites (Bonatti, 1992), however, are like those associated with hot spots-not the anemic volcanism and great ridge depth found in this location. Though the $15^{\circ} 20^{\prime}$ region is not representative of typical slow-spreading crust, ODP Leg 209 explored the pattern of shallow mantle flow during rifting by drilling 19 holes at 8 sites from $14^{\circ} 43^{\prime} \mathrm{N}$ to $15^{\circ} 39^{\prime} \mathrm{N}$ along the MAR (Kelemen et al., 2004). Most of the peridotites had little deformation, which was localized instead at high-temperature shear zones and brittle faults. This observation suggests that the mantle rose passively to the base of the thermal boundary layer at $15-20 \mathrm{~km}$ beneath the ridge, and then cooled, with subsequent corner flow at shallow depth accommodated along 
shear zones as the plates pulled apart (Kelemen et al., 2004). About 40 percent of the core represented small gabbro intrusions, confirming Cannat's interpretation (Kelemen et al., 2004).

At Hess Deep near the ultra-fastspreading East Pacific Rise (EPR), ODP Leg 147 drilled seven holes in gabbro at Site 894 and six holes in peridotite at Site 895. Gabbro was drilled up to $154.5 \mathrm{~m}$ downhole (30 percent recovery); peridotite was drilled up to $93.7 \mathrm{~m}$ downhole (20 percent recovery). Site 894 represents a high-level gabbro sequence near the sheeted dike-gabbro transition (Gillis et al., 1993; Pedersen et al., 1996), possibly the frozen substrate of an EPR magma lens (Natland and Dick, 1996). Analysis of these gabbros suggests that they are too iron-rich to be a source for EPR basalt or much of the lower crust (Natland and Dick, 1996). At Site 895, holes were drilled in peridotite across a dunite-filled melt transport conduit (Gillis et al., 1993). The peridotites are highly depleted compared to slow-spreading ridges, indicating a more depleted EPR shallow mantle (Dick and Natland, 1996). The dunites contain gabbro veins crystallized from mid-ocean ridge basalt (MORB) magmas (Arai and Matsukage, 1996; Dick and Natland, 1996) showing, for the first time, that whereas the process of mantle melting produces a range of melt compositions, these compositions aggregate in the mantle to form MORB before reaching the crust.

With the advent of the IODP, plans began again for total oceanic-crust penetration in the Pacific. As a start, Hole 1256D was drilled to $1507 \mathrm{mbsf}$ (1257-m subbasement) in 15 million-year-old super fast-spreading crust in the Pacific
Ocean (> $200 \mathrm{~mm} \mathrm{yr}^{-1}$ ) (Wilson et al., 2003). The site exploited the inverse relationship between spreading rate and depth to low-velocity zones (thought to represent magma chambers) along modern mid-ocean ridges to try and reach seismic layer 3 at shallow depth. Consistent with the Penrose model, IODP cored through $754 \mathrm{~m}$ of lavas, a short 57-m transition zone, $350 \mathrm{~m}$ of massive dikes, and into gabbros at 1407 mbsf (Figure 3) (Wilson et al., 2006). Gabbro was reached where predicted by the seismologists. Greenschist-facies minerals were found in the upper dikes, while deeper, highertemperature amphibolite-facies rocks were found, reflecting a steep geothermal gradient in the dikes. In the bottom $50 \mathrm{~m}$ of the hole, the dikes were recrystallized by intruding gabbro. The gabbros fall at

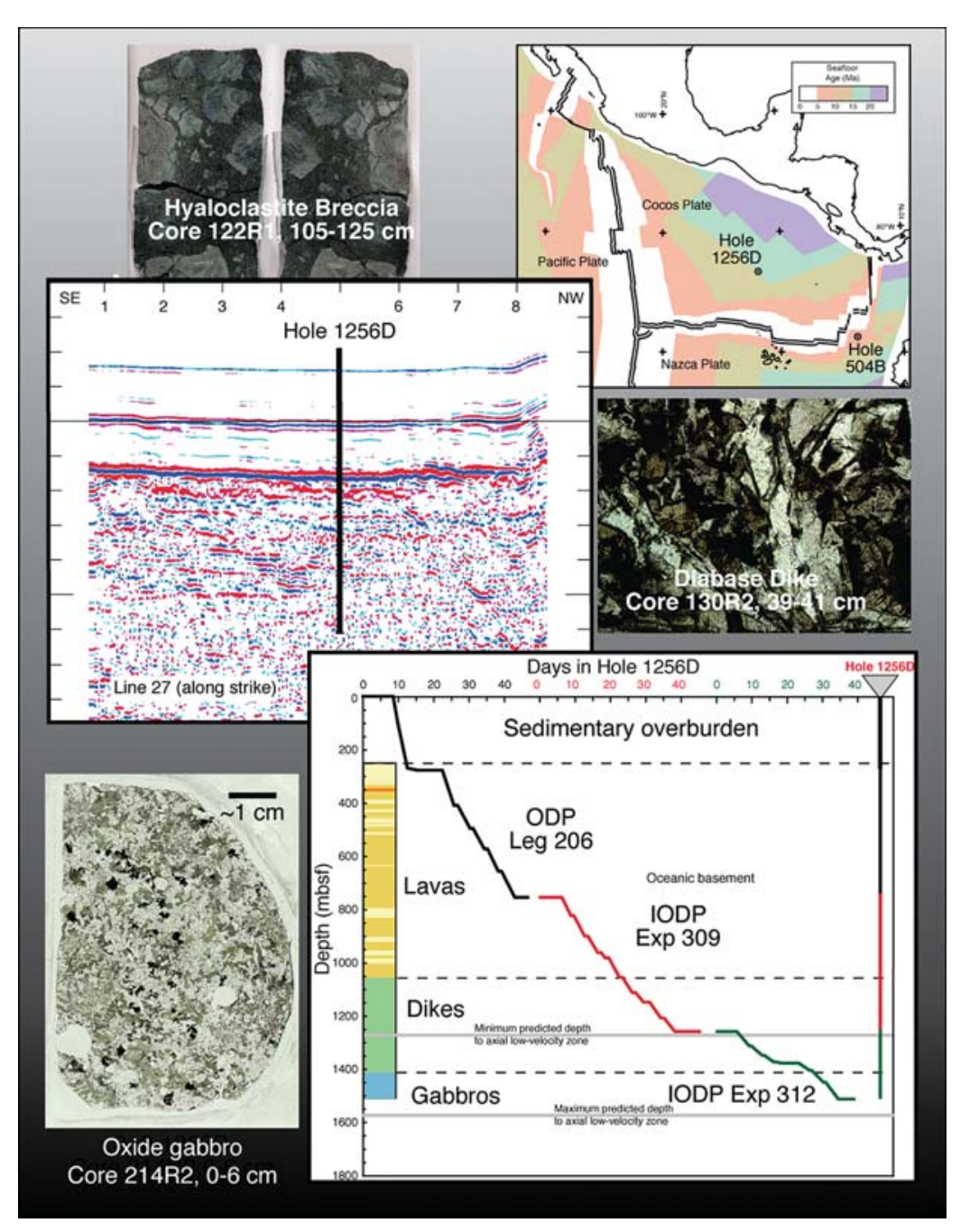

Figure 3. IODP Hole 1256D drilling location and results abstracted from the Expedition 309/312 Preliminary Report (http://iodp.tamu.edu/publications/PR/312PR/312PR.html). A hyaloclastite breccia, diabase dike, and gabbro are shown from each of the three principal stratigraphic horizons. 
the primitive end of Hole 1256D lavas and dikes, and closely resemble those exposed beneath sheeted dikes on the wall of Hess Deep and drilled in Hole 894G. As at Hess Deep, the lower crust could not form by subsidence of such highlevel evolved gabbro.

\section{DISCUSSION}

Where We Now Stand

Deep basement drilling in the oceans began 32 years ago with DSDP Leg 34 in 1974 amidst great hopes and expectations. It has proceeded in fits and starts, with great failures, and spectacular successes. In all, only 15 holes have reached $200 \mathrm{~m}$ below the top of igneous basement, and only four have penetrated greater than $600 \mathrm{~m}$ (Figure 2). Notably, once this depth is reached, drilling conditions improve remarkably: all four deep holes have penetrated greater than $1200 \mathrm{~m}$, and their failure was due largely to accidents and poor engineering. Only two holes, U1309D and 1256D, were actually planned and engineered for deep penetration, and both are still open. This success shows that we are finally learning how to drill deeply.

Here, we have focused on the results most pertinent to understanding crustal architecture-the original goal of deepocean drilling-testing the Penrose Model. This model appears to hold up well at the EPR, though seismic layer 2 thicknesses appear dependant on spreading rate. Again, at the intermediate-spreading-rate Cocos-Nazca Spreading Center, shallow crustal stratigraphy also fits the Penrose Model. At slow and ultraslow spreading ridges, a different situation emerges. No one model fits slow and ultraslow spread crust, with architecture varying with spreading rate and tectonic environment (Figure 1). There may even be areas where no organized stratigraphy exists (Karson, 1998; Lagabrielle et al., 1998). The studies at Atlantis Bank and Atlantis Massif, however, show that modified Penrose-type crust exists locally at slow and ultraslow ridges, though their different igneous stratigraphies suggest the internal structure of the lower crust may be quite variable at the segment scale. At the same time, the Cannat model (Figure 3) works well for the MAR near $15^{\circ} 20^{\prime}$ N. Finally, as discussed earlier, Hess-type crust formed at an ultra-fast spreading center also exists at ultraslow ridges at amagmatic segments.

\section{Where Do We Go from Here?}

Drilling accomplished to date shows that we can successfully explore the oceanic crust and mantle with well-planned programs using deep holes and offsetsection drilling. Big questions remain. It is certain that lower crust and mantle in tectonic windows unroofed at a rift valley wall is not fully representative of mature oceanic crust, particularly its extent and nature of alteration. We do not know how well the Penrose model fits the lower crust and the nature of Moho remains undetermined: is it a serpentinization front, a gradational intrusive boundary, a sharp contact between primitive gabbro and peridotite, or all of these (Figure 4)?

There is a consensus among Earth scientists that a total penetration of $\mathrm{Pa}$ cific crust is our highest priority and that working towards this goal, we should deepen Hole 1256D as soon as possible (Moho Workshop Participants, 2006). Thermal problems, however, prevent drilling to the Moho in "intact" oceanic crust except in water deeper than can be reached with the IODP's current 2500-m riser on the drillship Chikyu for at least 5 to 10 years. Moreover, a single deep hole in Pacific crust is a one-dimensional solution to a problem that is highly three dimensional within a spreading segment and among ocean basins. EPR crust represents one end-member for crustal formation. Site 1256 in super-fast crust, with its thin dike layer, appears to be an end-member for this end-member; it is therefore not representative of even "normal" Pacific Ocean crust. At least, another end-member in another ocean should be explored in detail, though more drilling investigations in different crustal regimes are required if we are truly to assess the composition of the oceanic crust and planet.

One drilling strategy is to immediately deepen Hole 1256D (Figure 3) in the Pacific Ocean as far as possible. At the same time, we need to determine if another site, more representative of Pacific crust, could be drilled (noting that penetration through the upper crust may or may not be done easily elsewhere). Although it may be difficult to obtain more than short sections at highly tectonized Hess Deep, another drilling leg there would provide a means to determine the lateral variability of EPR shallow mantle and deep crust at the segment scale. Thus, when a riser system becomes available for deep water, and a total penetration possible, the results can be put in context to assess the composition and architecture of Pacific crust and shallow mantle.

In the Atlantic and Indian Oceans, tectonic windows should be used to assess the variability of the lower crust and 
mantle at the segment scale by drilling a suite of 200- to 500-m offset holes in several locations. This drilling requires only two to three legs in relatively young crust ( $<3$ million years old $)$ at locations such as the Kane Megamullion and Atlantis Massif in the Atlantic where the geologic and geophysical controls required to drill already exist. Because drilling the lower crust at one location is unlikely to be representative, Hole U1309D in the Atlantic should be deepened as far as possible to enable comparison of its stratigraphy to a deep Hole at Atlantis Bank in the Indian Ocean. An offset hole should also be drilled near U1309D that is located in the best possible place to test whether fresh mantle peridotite is really present at shallow depth as suggested by the seismic data.

While penetration to the Moho in "intact" slow-spread crust is not possible now, we should obtain a composite section by drilling partial sections. Atlantis Bank, situated at 700-m water depth in the Indian Ocean, offers the best opportunity to drill the igneous crust-mantle boundary and the (seismic) Moho by virtue of easy drilling conditions, low temperatures, short pipe-trip time, and a crustal age of 12 million years (Moho would be attainable by drilling to $\sim 5 \mathrm{~km} \mathrm{mbsf}$ ). Drilling at the Atlantis Bank, however, will not recover typical slow-spread oceanic structure or alteration. Another option is a deep penetration well into seismic layer 3 into "intact" Atlantic crust in the vicinity of DSDP Site 332. The water depth there is less than $2000 \mathrm{~m}$, which allows use of Chikyu's riser system. Because of to the young age ( 3.5 million years old) of the crust here, it is likely that ther-

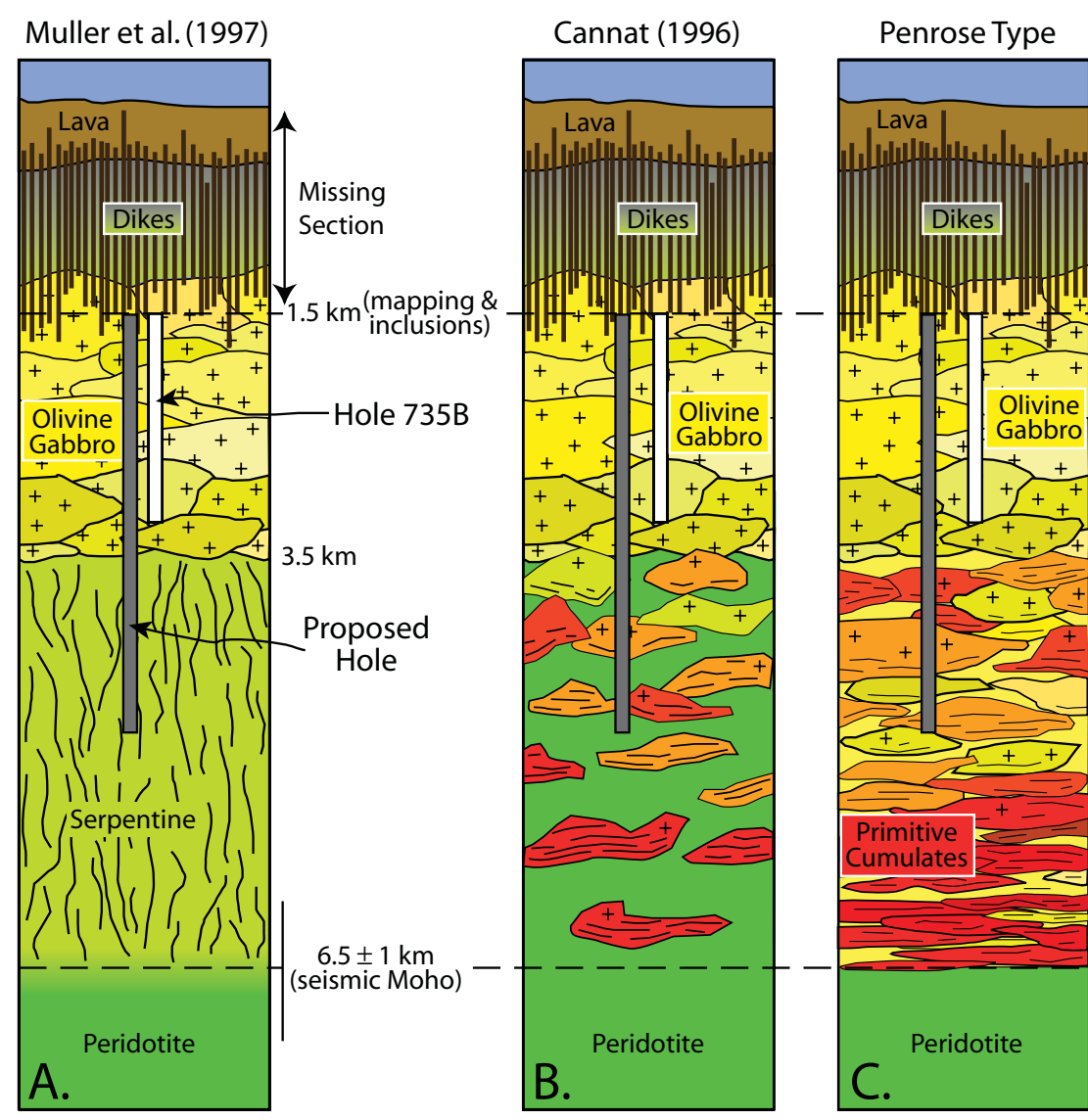

Figure 4. Alternate interpretations of the crust-mantle boundary according to (A) Muller et al. (1997), (B) Cannat (1996), and (C) a Penrose model (following Dick [1991a] and Nisbet and Fowler [1978]), showing the current proposed depth for drilling the first stage of a new hole at Atlantis Bank. Upper dashed line shows the likely horizon of the detachment faults at Atlantis Bank and Atlantis Massif.

mal problems may end drilling before the Moho is reached. This possibility remains to be tested. Most of these sites are thoroughly surveyed and extensively reviewed. Thus, we are ready to answer major global questions about the architecture and composition of the oceanic crust and shallow mantle.

\section{ACKNOWLEDGEMENTS}

The authors thank S. Carbotte and an anonymous reviewer. Preparation and research for this paper was supported by National Science Foundation Division of Ocean Sciences Grant 042612.

\section{REFERENCES}

Alt, J.C., H. Kinoshita, and L.B. Stokking. 1993. Proceedings of the Ocean Drilling Program, Initial Reports, v. 148. Texas A\&M University, Ocean Drilling Program, College Station, TX, 311 pp.

Arai, S., and K. Matsukage. 1996. Petrology of gabbro-troctolite-peridotite complex from Hess Deep, equatorial Pacific: Implications for mantle-melt interaction within the oceanic lithosphere. Pp. 57172 in Proceedings of the Ocean Drilling Program, v. 147, C. Mevel, K.M. Gillis, J.F. Allan, and P.S. Meyer, eds. Texas A\&M University, Ocean Drilling Program, College Station, TX.

Bascom, W. 1961. A Hole in the Bottom of the Sea. Doubleday and Company, Garden City, NY, 352 pp.

Blackman, D.K., J.R. Cann, R. Janssen, and D.K. Smith. 1998. Origin of extensional core complexes: Evidence from the Mid-Atlantic Ridge at Atlantis Fracture Zone. Journal of Geophysical Research 103:21,315-21,333.

Blackman, D.K., B. Ildefonse, B.E. John, Y. Ohara, D.J. Miller, and C.J. Macleod. 2006. Proceedings of the Integrated Ocean Drilling Program, v. 304/305. 
Integrated Ocean Drilling Program, College Station, TX.

Bonatti, E., J. Honnorez, and G. Ferrara. 1971. Peridotite-gabbro-basalt complex from the equatorial Mid-Atlantic Ridge. Philosophical Transactions of the Royal Society of London A 268:385-402.

Bonatti, E., A. Peyve, P. Kepezhinskas, N. Kurentsova, M. Seyler, S. Skolotnev, and G. Dintsev. 1992. Upper mantle heterogeneity below the Mid-Atlantic Ridge, $0^{\circ}-15^{\circ} \mathrm{N}$. Journal of Geophysical Research 97:4,461-4,476.

Cann, J.R. 1974. A model for oceanic crustal structure developed. Geophysical Journal of the Royal Astronomical Society 39:169-187.

Cannat, M. 1993. Emplacement of mantle rocks in the seafloor at mid-ocean ridges. Journal of Geophysical Research 98:4,163-4,172.

Cannat, M. 1996. How thick is the magmatic crust at slow spreading oceanic ridges. Journal of Geophysical Research 101:2,847-2,857.

Cannat, M., C. Mével, M. Maia, C. Deplus, C. Durand, P. Gente, P. Agrinier, A. Belarouchi, G. Dubuisson, E. Humler, and J. Reynolds. 1995. Thin crust, ultramafic exposures, and rugged faulting patterns at the Mid-Atlantic Ridge $\left(22^{\circ}-24^{\circ} \mathrm{N}\right)$. Geology 23:49-52.

Cannat, M., Y. Lagabrielle, H. Bougault, J. Casey, N. de Coutures, L. Dmitriev, and Y. Fouquet. 1997. Ultramafic and gabbroic exposures at the Mid-Atlantic Ridge: Geologic mapping in the $15^{\circ} \mathrm{N}$ region. Tectonophysics 279:193-213.

Collins, J.A., and R.S. Detrick. 1998. Seismic structure of the Atlantis Fracture Zone megamullion, a serpentinized ultramafic massif. Eos Transaction of the American Geophysical Union 79:800 (abstract).

Collins, J.A., B. Tucholke, and J.P. Canales. 2001. Structure of Mid-Atlantic Ridge megamullions from seismic refraction experiments and multi-channel seismic reflection profiling. Eos Transaction of the American Geophysical Union 83:EAE03-A-10390 (Abstract).

Conference Participants. 1972. Penrose Field Conference: Ophiolites. Geotimes 17:24-25.

Detrick, R., J. Collins, R. Stephen, and S. Swift. 1994. In situ evidence for the nature of the seismic layer $2 / 3$ boundary in oceanic crust. Nature 370:288-290.

Dick, H.J.B. 1989a. Abyssal peridotites, very slow spreading ridges and ocean ridge magmatism. In: Magmatism in the Ocean Basins, A.D. Saunders and M.J. Norry, eds. Geological Society Special Publication 42:71-105.

Dick, H.J.B. 1989b. Drilling the Oceanic Lower Crust and Mantle. JOI/USSAC Workshop Report. Woods Hole Oceanographic Institution, Woods Hole, MA, 115 pp.

Dick, H.J.B., and C. Mével. 1996. The Ocean Lithosphere and Scientific Drilling into the 21st Century. JOI/U.S. Science Support Program and InterRidge, Washington, D.C., 89 pp.

Dick, H.J.B., and J.H. Natland. 1996. Late stage melt evolution and transport in the shallow mantle beneath the East Pacific Rise. Pp. 103-134 in Proceedings of the Ocean Drilling Program, Scientific Results, v. 147, K. Gillis, C. Mevel, and J. Allan, eds. Texas A\&M University, Ocean Drilling Program, College Station, TX.

Dick, H.J.B., P.S. Meyer, S. Bloomer, S. Kirby, D. Stakes, and C. Mawer. 1991a. Lithostratigraphic evolution of an in-situ section of oceanic layer 3. Pp. 439-540 in Proceedings of the Ocean Drilling Program, Scientific Results, v. 118, R.P. Von Herzen, P.T. Robinson et al., eds. Texas A\&M University, Ocean Drilling Program, College Station, TX.

Dick, H.J.B., J.A. Erzinger, and L.B. Stokking. 1992. Proceedings of the Ocean Drilling Program, Initial Reports, v. 140. Texas A\&M University, Ocean Drilling Program, College Station, TX, 408 pp.

Dick, H.J.B., J.H. Natland, D.J. Miller, et al. 1999. Proceedings of the Ocean Drilling Program, Initial Reports, v. 176. Texas A\&M University, Ocean Drilling Program, College Station, TX. [Online] Available at: http://www-odp.tamu.edu/publications/176_ IR/176TOC.HTM [last accessed October 4, 2006].

Dick, H.J.B., J.H. Natland, JC. Alt, W. Bach, D. Bideau, J.S. Gee, S. Haggas, J.G.H. Hertogen, G. Hirth, P.M. Holm, B. Ildefonse, G.J. Iturrino, B.E. John, D.S. Kelley, E. Kikawa, A. Kingdon, P.J. LeRoux, J. Maeda, P.S. Meyer, D.J. Miller, H.R. Naslund, Y.-L. Niu, P.T. Robinson, J. Snow, R.A. Stephen, P.W. Trimby, H.-U. Worm, and A. Yoshinobu. 2000. A long in-situ section of the lower ocean crust: Results of ODP Leg 176 drilling at the Southwest Indian Ridge. Earth and Planetary Sciences 179:31-51.

Dick, H.J.B., J. Lin, and H. Schouten. 2003. An ultraslow-spreading class of ocean ridge. Nature 426:405-412.

Dosso, L., B.B. Hanan, H. Bougault, J.-G. Schilling, and J.-L. Joron. 1991. Sr-Nd-Pb geochemical morphology between 10 degrees and 17 degrees $\mathrm{N}$ on the Mid-Atlantic Ridge: A new MORB isotope signature. Earth and Planetary Science Letters 106:29-43.

Engel, C.G., and R.L. Fisher. 1969. Lherzolite, anorthosite, gabbro, and basalt dredged from the Mid-Indian Ocean Ridge. Science 166:1,136-1,141.

Engel, A.E.J., C.G. Engel, and R.G. Havens. 1965. Chemical characteristics of oceanic basalts and the upper mantle. Geological Society of America Bulletin 76:719-734.

Gillis, K., C. Mével, J. Allan, et al. 1993. Proceedings of the Ocean Drilling Program, Initial Reports, v. 147 Texas A\&M University, Ocean Drilling Program, College Station, TX, $352 \mathrm{pp}$.

Hess, H.H. 1962. The history of the ocean basins. Pp.599-620 in Petrologic Studies: A Volume in Honor of A.F. Buddington, A.E.J. Engel, H.L. James, and B.F. Leonard, eds. Geological Society of America, Boulder, CO.

Karson, J.A. 1998. Internal structure of oceanic lithosphere: A perspective from tectonic windows. Pp. 177-218 in Faulting and Magmatism at Mid-Ocean Ridges, W. Buck, P.T. Delaney, J.A. Karson, and Y. Lagabrielle, eds. Geophysical Monograph 106. American Geophysical Union, Washington, D.C.

Kelemen, P.B., E. Kikawa, D.J. Miller, et al. 2004. Proceedings of the Ocean Drilling Program, Initial Reports, Volume 209, Texas A\&M University, Ocean Drilling Program, College Station, TX. [Online] Available at: : http://www-odp.tamu.edu/publications/209_IR/209TOC.HTM [last accessed October 4,2006$]$.

Lagabrielle, Y., D. Bideau, M. Cannat, J.A. Karson, and C. Mével. 1998. Ultramafic-mafic plutonic rocks suites exposed along the Mid-Atlantic Ridge $\left(10^{\circ} \mathrm{N}-30^{\circ} \mathrm{N}\right)$ Symmetrical-asymmetrical distribution and implications for seafloor spreading processes. Pp.153-176 in Faulting and Magmatism at Mid-Ocean Ridges, W. Buck, P.T. Delaney, J.A. Karson, and Y. Lagabrielle, eds. Geophysical Monograph 106. American Geophysical Union, Wash- ington, D.C.

Matsumoto, T., H.J. Dick, and A. Cruise. 2002. In-situ observation of the lower crust and upper mantle lithology in Atlantis Bank, SWIR-Results from ABCDE Cruise. EOS Transactions of the American Geophysical Union 83.

Michael, P.J., C.H. Langmuir, H.J.B. Dick, J.E. Snow, S.L. Goldstein, D.W. Graham, K. Lehnert, G. Kurras, R. Mühe, and H.N. Edmonds. 2003. Magmatic and amagmatic seafloor spreading at the slowest mid-ocean ridge: Gakkel Ridge, Arctic Ocean. $\mathrm{Na}$ ture 423:956-961.

Muller, M.R., C.J. Robinson, T.A. Minshull, R.S. White, and M.J. Bickle. 1997. Thin crust beneath ocean drilling program borehole $735 \mathrm{~B}$ at the Southwest Indian Ridge? Earth and Planetary Science Letters 148:93-107.

Natland, J.H., and H.J.B. Dick. 1996. Melt migration through high-level gabbroic cumulates of the East Pacific Rise at Hess Deep: The origin of magma lenses and the deep crustal structure of fast-spreading ridges. Pp. 21-58 in Proceedings of the Ocean Drilling Program, v. 147, C. Mevel, K.M. Gillis, J.F. Allan, and P.S. Meyer, eds. Texas A\&M University, Ocean Drilling Program, College Station, TX.

Nisbet, E.G., and C.M.R. Fowler. 1978. The Mid-Atlantic Ridge at 37 and $45^{\circ} \mathrm{N}$ : Some geophysical and petrological constraints. Geophysical Journal of the Royal Astronomical Society 54:631-660.

Pedersen, R.B., J. Malpas, and T. Falloon. 1996. Petrology and geochemistry of gabbroic and related rocks from Site 894, Hess Deep. Pp. 1-20 in Proceedings of the Ocean Drilling Program, v. 147, C. Mevel, K.M. Gillis, J.F. Allan, and P.S. Meyer, eds. Texas A\&M University, Ocean Drilling Program, College Station, TX,

Robinson, P.T., R. Von Herzen, et al. 1989. Proceedings of the Ocean Drilling Program, Initial Reports. Texas A\&M University, Ocean Drilling Program, College Station, TX, 826 pp.

Sinton, J.M., and R.S. Detrick. 1992. Mid-Ocean Ridge magma chambers. Journal of Geophysical Research 97:197-216.

Whitehead, J.A., Jr., H.J.B. Dick, and H. Schouten. 1984. A mechanism for magmatic accretion under spreading centres. Nature 312:146-148.

Wilson, D., D.A.H. Teagle, G.D. Acton, et al. 2003. Proceedings of the Ocean Drilling Program, Initial Reports, Volume 206, Texas A\&M University, Ocean Drilling Program, College Station, TX. [Online] Available at: http://www-odp.tamu.edu/publications/206_IR/206TOC.HTM [last accessed October 4,2006$]$.

Wilson, D.S., A.H. Teagle, J.C. Alt, N.R. Banerjee, S. Umino, S. Miyashita, G.D. Acton, R. Anma, S.M. Barr, A. Belghoul, J. Carlut, D.M. Christie, R.M. Coggon, K.M. Cooper, C. Cordier, L. Crispini, S. Rodgriguez Durand, F. Einaudi, L. Galli, Y. Gao, J. Geldmacher, L.A. Gilbert, N.W. Hayman, E. Herrero-Bervera, N. Hirano, S. Holter, S. Ingle, S. Jiang, U. Kalberkamp, M. Kemeklian, J. Koepke, C. Laverne, H.L. Lledo Vasquez, J. Maclennan, S. Morgan, N. Neo, H.J. Nichols, S.-H. Park, M.K. Reichow, T. Sakuyama, T. Sano, R. Sandwell, B. Scheibner, C.E. Smith-Duque, S.A. Swift, P. Tartorotti, A.A. Tikku, M. Tominaga, E.A. Veloso, T. Yamasaki, S. Yamazaki, and C. Ziegler. 2006. Drilling to gabbro in intact ocean crust. Science 312:1,016-1,020. 